Zeszyty Naukowe Szkoły Głównej Gospodarstwa Wiejskiego

Ekonomika i Organizacja Gospodarki Żywnościowej nr 120, 2017: 69-81

DOI 10.22630/EIOGZ.2017.120.39

\title{
Arkadiusz Weremczuk
}

Wydział Nauk Ekonomicznych

Szkoła Główna Gospodarstwa Wiejskiego w Warszawie

\section{Dotowane ubezpieczenia upraw w Polsce. Stan i perspektywy}

\section{Wstęp}

Rolnictwo bardziej niż inne działy gospodarki jest narażone na niekorzystne skutki oddziaływanie czynników przyrodniczych, co determinuje potrzebę wsparcia ze środków publicznych ochrony ubezpieczeniowej działalności gospodarstw wiejskich.

Od dłuższego czasu trwają modyfikacje krajowego systemu dotowanych ubezpieczeń upraw, dla którego aktualnie weryfikowane są zasady przejściowe. Kluczowym problemem w tym obszarze jest brak powszechności stosowania przez rolników ochrony ubezpieczeniowej upraw. Sytuacja taka wynika głównie z dwóch powodów: po pierwsze produkty te uważane są za zbyt drogie, a po drugie regulacje związane $\mathrm{z}$ ich aplikacją są zbyt skomplikowane. W rezultacie do 2016 roku ochroną ubezpieczeniową objętych było w Polsce nie więcej niż 25\% gruntów, co stanowi o połowę mniej niż minimum wymagane ustawą oraz przepisami unijnymi: ustawą z dnia 7 lipca 2005 roku o ubezpieczeniach upraw rolnych i zwierząt gospodarskich [Dz.U. 2005 nr 150, poz. 1249, z późn. zm.] oraz rozporządzeniem Komisji (WE) 1857/2006 [Dz.Urz. UE L 358/3]. W niniejszej pracy zaproponowano dwa warianty usprawnień służących zwiększeniu zainteresowania rolników ubezpieczaniem upraw. Rozwiązania te wykraczają poza dotychczas rozważane sugestie [Lorant i Fekete 2015, Piet i Bougherara 2016] i są zgodne z założeniami wspólnej polityki rolnej na lata 2014-2020. 


\section{Cele i metodyka badań}

Celem pracy jest ocena obowiązujących zasad funkcjonowania dotowanych ubezpieczeń upraw w Polsce, a także wskazanie propozycji działań służących zwiększeniu powszechności stosowania tych instrumentów przez rolników.

Badanie przeprowadzono, wykorzystując dane pochodzące ze źródeł wtórnych (metoda analizy źródeł zastanych - ang. desk research), w tym dostępnej literatury fachowej, aktów prawnych oraz zestawień statystycznych Głównego Urzędu Statystycznego, Ministerstwa Rolnictwa i Rozwoju Wsi, Polskiej Izby Ubezpieczeń oraz Komisji Nadzoru Finansowego.

Analizę przeprowadzono dla okresu 2012-2016, ponieważ właśnie w tym terminie, na szczeblu administracji centralnej rozważano zmianę systemu dotowanych ubezpieczeń upraw, mającą skutkować zwiększeniem powszechności tych produktów wśród producentów rolnych.

W analizie danych wykorzystano wskaźniki struktury, dynamiki, udziału powierzchni ubezpieczonych upraw w powierzchni upraw ogółem.

\section{Krótki rys historyczny ubezpieczeń upraw w Polsce}

Pierwsze ubezpieczenia rolne stosowano w Polsce już od średniowiecza w postaci kas ogniowych i związków glebowych [Łyskawa 2015], ale dopiero w XX wieku przyjęły one formę rozwiązań systemowych.

W rozporządzeniu Prezydenta Rzeczypospolitej z dnia 27 maja 1927 roku o przymusie ubezpieczenia od ognia i o Powszechnym Zakładzie Ubezpieczeń Wzajemnych [Dz.U. R.P. 1927 nr 46, poz. 410] wprowadzono możliwość ustanawiania przez sejmiki wojewódzkie obowiązku ubezpieczania plonów od ryzyka gradu. Przedmiotem ubezpieczenia były wówczas zboża w ziarnie, słoma i pasze, jak również rośliny techniczne, takie jak: len, tytoń i chmiel. Rozporządzenie jednakże z obowiązku ubezpieczeniowego wyłączało: okopowizny, ziemiopłody na pniu, poślady, zgoniny, plewy, słomę roślin oleistych oraz nawóz [Malik 2016]. Jak piszą Janowicz-Lomott i Łyskawa [2016], „Faktyczny, ilościowy rozwój ubezpieczeń dla rolnictwa nastapił jednak w okresie 1947-1952, kiedy to ubezpieczenia upraw zaczęly mieć charakter obowiązkowy". Ustawa z dnia 28 marca 1952 roku o ubezpieczeniach państwowych [Dz.U. $1952 \mathrm{nr}$ 20, poz. 130] upoważniała Radę Ministrów między innymi do wydania rozporządzeń regulujących zakres obowiązkowych ubezpieczeń mienia ruchomego oraz upraw. 
Rozporządzenie Rady Ministrów z dnia 1 lutego 1972 roku w sprawie obowiązkowego ubezpieczenia ziemiopłodów od gradobicia i powodzi [Dz.U. 1972 r. $\mathrm{nr} 5$, poz. 25] rozszerzało zakres przedmiotowy ochrony ubezpieczeniowej o rośliny pastewne uprawiane na paszę jako plon główny, poplon lub śródplon, ziarno, siano lub zieloną masę od ryzyka gradu i powodzi. Rośliny okopowe uprawiane na paszę i buraki cukrowe były ubezpieczane tylko od ryzyka powodzi. W przypadku łąk i pastwisk ochroną ubezpieczeniową objęte były trawy nieskoszone, siano lub zielona masa od ryzyka powodzi.

Na mocy ustawy z dnia 20 września 1984 roku o ubezpieczeniach majątkowych i osobowych [Dz.U. $1984 \mathrm{nr}$ 45, poz. 242] ubezpieczeniu obowiązkowemu podlegały:

- budynki - od ognia, huraganu, powodzi i innych zdarzeń losowych,

- mienie ruchome związane z prowadzeniem gospodarstwa rolnego, jak również mienie ruchome posiadaczy budynków na działkach o powierzchni do 0,5 ha - od ognia, huraganu, powodzi i innych zdarzeń losowych,

- uprawy zbóż oraz roślin okopowych i pastewnych - od gradobicia, ognia, powodzi i zalania wskutek nadmiernych opadów atmosferycznych,

- konie i bydło $\mathrm{w}$ wieku przydatności produkcyjnej oraz trzoda chlewna, z wyjątkiem prosiąt - od padnięcia i uboju z konieczności,

- odpowiedzialność cywilna rolników za szkody powstałe w związku z prowadzeniem indywidualnego gospodarstwa rolnego oraz za szkody wyrządzone w życiu prywatnym.

Kolejną istotną zmianę $\mathrm{w}$ ubezpieczeniach rolnych wprowadzono ustawą z dnia 28 lipca 1990 roku o działalności ubezpieczeniowej [Dz.U. $1990 \mathrm{nr}$ 59, poz. 344], która zniosła obligatoryjny charakter ubezpieczeń upraw w Polsce. Rolnicy zostali jednocześnie zobowiązani do nabywania ubezpieczenia odpowiedzialności cywilnej rolników z tytułu posiadania gospodarstwa rolnego i ubezpieczenia budynków wchodzących w skład gospodarstwa rolnego od ognia $\mathrm{i}$ innych zdarzeń losowych. Wprowadzenie tej ustawy spowodowało drastyczny spadek liczby zawieranych umów ubezpieczenia upraw (z2,9 mln umów w $1988 \mathrm{r}$. do 45 tys. umów w 2001 r.) [Rojewski 2012].

Po 2000 roku ważne modyfikacje systemu ubezpieczeń upraw wywołała akcesja Polski do Unii Europejskiej i uchwalenie 7 lipca 2005 roku ustawy o ubezpieczeniach upraw rolnych i zwierząt gospodarskich, która wprowadziła dotacje państwowe do składek ubezpieczeniowych. W konsekwencji realizacji tej ustawy od 2008 roku istnieje obowiązek ubezpieczania upraw dla producentów rolnych. 


\section{Aktualne zasady udzielania dotacji państwowych do ubezpieczeń rolnych w Polsce}

W okresie od 2006 do 2016 roku w wyniku kolejnych nowelizacji ustawy z 2005 roku [Dz.U. $2005 \mathrm{nr}$ 150, poz. 1249] wielkość dotacji do składek ubezpieczeniowych ulegała zmianie, w zależności od wysokości składek oraz sumy ubezpieczenia i oscylowała w przedziale od 35 do $50 \%$.

Na podstawie doświadczeń ostatniej dekady w 2017 roku wprowadzono okres przejściowy, w którym dopłaty z budżetu państwa do składek ubezpieczeniowych producentów rolnych przysługują w wysokości do $65 \%$ składki, pod warunkiem zawarcia przez rolnika umowy obejmującej pakiet przewidzianych ustawą rodzajów ryzyka. Dopłaty warunkowane są poziomem naliczanej przez zakład ubezpieczeniowy składki, która nie może przekraczać 9\% sumy ubezpieczenia. Jeżeli działalność producenta rolnego jest prowadzona na gruntach klasy V, stawka taryfowa nie może przekraczać $12 \%$, a w odniesieniu do klasy VI - $15 \%$ sumy ubezpieczenia.

Według ustawy w przypadku umowy ubezpieczenia od jednego rodzaju ryzyka lub łącznie od kilku wybranych rodzajów ryzyka przekroczenie wymienionych wcześniej stawek taryfowych $(9,12$ i 15\%) skutkuje tym, że dopłata nie przysługuje. W 2017 roku obowiązuje jednak przepis przejściowy umożliwiający ubezpieczenie przez producenta rolnego upraw rolnych od jednego lub łącznie od kilku wybranych rodzajów ryzyka z zachowaniem możliwości skorzystania

Tabela 1

Rozpiętość wysokości stawek taryfowych ubezpieczenia dla wybranych upraw rolnych

\begin{tabular}{|l|c|c|c|c|}
\hline \multirow{2}{*}{ Rodzaj uprawy } & \multicolumn{4}{|c|}{ Wybrane rodzaje ryzyka } \\
\cline { 2 - 5 } & powódź & $\begin{array}{c}\text { ujemne skutki } \\
\text { przezimowania }\end{array}$ & $\begin{array}{c}\text { przymrozki } \\
\text { wiosenne }\end{array}$ & susza \\
\cline { 2 - 5 } & \multicolumn{4}{|c|}{ \% sumy ubezpieczenia* } \\
\hline Zboża ozime & $1,5-12,0$ & $1,8-8,0$ & $0,5-3,6$ & $2,0-15,0$ \\
\hline $\begin{array}{l}\text { Rzepak } \\
\text { ozimy }\end{array}$ & $1,5-12,0$ & $3,6-10,0$ & $1,0-4,8$ & $2,0-15,0$ \\
\hline Kukurydza & $1,5-12,0$ & - & $1,0-3,0$ & $2,0-17,0$ \\
\hline Chmiel & $1,5-12,0$ & - & $1,0-3,0$ & $2,0-16,0$ \\
\hline Warzywa & $1,5-12,0$ & $2,0-9,0$ & $1,0-5,0$ & $2,0-18,0$ \\
\hline Truskawki & $1,5-12,0$ & $2,0-9,0$ & $1,0-7,2$ & $2,0-17,0$ \\
\hline Ziemniaki & $1,5-12,0$ & - & $1,0-5,0$ & $2,0-15,0$ \\
\hline
\end{tabular}

*Wysokość składki jest uzależniona od rodzaju gleby, położenia działki, rodzaju rośliny. Źródło: Opracowanie własne na podstawie danych z uzasadnienia do rządowego projektu ustawy o zmianie ustawy o ubezpieczeniach upraw rolnych i zwierząt gospodarskich oraz ustawy o opłacie skarbowej [anonim (b.d.)a]. 
z dofinansowania z budżetu państwa do składek ubezpieczenia. Jeśli składka ubezpieczyciela przekracza poziom taryfy określonej w ustawie, wówczas dopłaty do składki są realizowane do wysokości ustalonego w przepisach limitu, a pozostałą cześć składki pokrywa rolnik.

Jak wynika $\mathrm{z}$ analiz zakładów ubezpieczeniowych, związanych umową z Ministerstwem Rolnictwa i Rozwoju Wsi w sprawie dopłat do składek ubezpieczeń upraw rolnych, szacowane składki ubezpieczeń upraw od wszystkich rodzajów ryzyka niejednokrotnie przewyższały maksymalne taryfy przewidziane w ustawie. Przykładowe wysokości stawek taryfowych ubezpieczenia dla wybranych upraw rolnych zostały przedstawione w tabeli 1 .

\section{Rodzaje zdarzeń kwalifikujących się do ochrony ubezpieczeniowej upraw w Polsce}

Ustawodawca zdefiniował 10 zdarzeń, od których producenci rolni mogą się ubezpieczyć. Ryzyko to można zaliczyć do dwóch grup. Pierwszą z nich stanowią rodzaje ryzyka o charakterze katastroficznym, które swoim zasięgiem mogą obejmować obszar całego kraju i spowodować ogromne straty szacowane na miliardy złotych. Tabela 2 przedstawia rodzaje ryzyka o charakterze katastroficznym w ubezpieczeniu upraw.

\section{Tabela 2}

Rodzaje ryzyka o charakterze katastroficznym - definicje

\begin{tabular}{|l|l|}
\hline $\begin{array}{l}\text { Rodzaje ryzyka } \\
\text { o charakterze } \\
\text { katastroficznym }\end{array}$ & \multicolumn{1}{|c|}{ Ustawowa definicje poszczególnych rodzajów ryzyka } \\
\hline Susza & $\begin{array}{l}\text { szkody spowodowane wystapieniem, w dowolnym sześciodekadowym okresie } \\
\text { od 21 marca do } 30 \text { września, spadku klimatycznego bilansu wodnego poniżej } \\
\text { wartości określonej dla poszczególnych gatunków roślin uprawnych i gleb }\end{array}$ \\
\hline $\begin{array}{l}\text { Ujemne skutki } \\
\text { przezimowania }\end{array}$ & $\begin{array}{l}\text { Oznaczają szkody spowodowane wymarznięciem, wymoknięciem, wypa- } \\
\text { rzeniem, wysmaleniem lub wysadzeniem roślin, w okresie od 1 grudnia do } \\
\text { 30 kwietnia, polegające na całkowitym lub częściowym zniszczeniu roślin lub } \\
\text { całkowitej utracie plonu lub jego części }\end{array}$ \\
\hline $\begin{array}{l}\text { Przymrozki } \\
\text { wiosenne }\end{array}$ & $\begin{array}{l}\text { oznaczaja szkody spowodowane przez obniżenie się temperatury poniżej } \\
\text { 0C, w okresie od 15 kwietnia do 30 czerwca, polegające na całkowitym lub } \\
\text { częściowym zniszczeniu roślin lub całkowitej utracie plonu lub jego części }\end{array}$ \\
\hline Powódź & $\begin{array}{l}\text { oznaczają szkody powstałe wskutek: } \\
\text { a) zalania terenów w następstwie podniesienia się poziomu wód płynących } \\
\text { lub stojących } \\
\text { b) zalania terenów wskutek deszczu nawalnego } \\
\text { c) spływu wód po zboczach lub stokach na terenach górskich i podgórskich }\end{array}$ \\
\hline
\end{tabular}

Źródło: Opracowanie własne na podstawie ustawa z dnia 7 lipca 2005 roku o ubezpieczeniach upraw rolnych i zwierząt gospodarskich [Dz.U. 2016, poz. 792, z późn. zm.]. 
Drugą grupę stanowią pozostałe rodzaje ryzyka o charakterze lokalnym, które nie powodują znaczących szkód w odniesieniu do ogólnej powierzchni upraw (tab. 3). Dobrym przykładem takich zdarzeń jest ryzyko gradu, przed którym rolnicy mogą zabezpieczać się indywidualnie z użyciem sieci antygradowych lub dział przeciwgradowych.

Tabela 3

Pozostałe rodzaje ryzyka w ubezpieczeniu upraw rolnych

\begin{tabular}{|l|l|}
\hline $\begin{array}{l}\text { Pozostałe rodzaje } \\
\text { ryzyka }\end{array}$ & \multicolumn{1}{c|}{ Ustawowa definicja ryzyka } \\
\hline Huragan & $\begin{array}{l}\text { oznaczają szkody powstałe w wyniku działania wiatru o prędkości nie } \\
\text { mniejszej niż 24 m/s, którego działanie wyrządza masowe szkody; } \\
\text { pojedyncze szkody uważa się za spowodowane przez huragan, jeżeli } \\
\text { w najbliższym sasiedztwie stwierdzono działanie huraganu }\end{array}$ \\
\hline Deszcz nawalny & $\begin{array}{l}\text { oznaczają szkody powstałe wskutek deszczu o współczynniku wydaj- } \\
\text { ności o wartości co najmniej 4; w przypadku braku możliwości ustalenia } \\
\text { tego współczynnika bierze się pod uwage stan faktyczny i rozmiar szkód } \\
\text { w miejscu ich powstania, świadczące wyraźnie o działaniach deszczu } \\
\text { nawalnego }\end{array}$ \\
\hline Grad & $\begin{array}{l}\text { oznaczają szkody powstałe wskutek opadu atmosferycznego składaja- } \\
\text { cego się z bryłek lodu }\end{array}$ \\
\hline Piorun & $\begin{array}{l}\text { oznaczają szkody będące następstwem wyładowania atmosferycznego } \\
\text { pozostawiającego bezsporne ślady tego zdarzenia }\end{array}$ \\
\hline Obsunięcie się & $\begin{array}{l}\text { oznaczają szkody spowodowane przez zapadanie się ziemi oraz usu- } \\
\text { wanie się ziemi, z tym że za szkody spowodowane przez: } \\
\text { a) zapadanie się ziemi - uważa się szkody powstałe wskutek obniżenia } \\
\text { się terenu z powodu zawalenia się podziemnych wolnych przestrzeni } \\
\text { w gruncie } \\
\text { b) usuwanie się ziemi - uważa się szkody powstałe wskutek ruchów } \\
\text { ziemi na stokach }\end{array}$ \\
\hline Lawiny & $\begin{array}{l}\text { oznaczają szkody powstałe wskutek gwałtownego zsuwania się lub } \\
\text { staczania ze zboczy górskich lub podgórskich mas śniegu, lodu, skał, } \\
\text { kamieni, ziemi lub błota }\end{array}$ \\
\hline
\end{tabular}

Źródło: Opracowanie własne na podstawie ustawa z dnia 7 lipca 2005 roku o ubezpieczeniach upraw rolnych i zwierząt gospodarskich [Dz.U. 2016, poz. 792, z późn. zm.]

Zgodnie z ustawą rolnicy, którzy nie ubezpieczą co najmniej 50\% powierzchni swoich upraw rolnych, na które uzyskali płatności bezpośrednie do gruntów rolnych, są zobowiązani do wniesienia opłaty karnej w kwocie 2 euro za 1 ha [Dz.U. $2005 \mathrm{nr} \mathrm{150,} \mathrm{poz.} \mathrm{1249].}$ 


\section{Obszar upraw objęty ochroną ubezpieczeniową w Polsce w latach 2012-2016}

Faktyczny obszar pól objęty ochroną w latach 2012-2016 wynosił średnio rocznie około $3 \mathrm{mln}$ ha (tab. 4). Tym czasem zgodnie z ustawą o ubezpieczeniach upraw rolnych i zwierząt gospodarskich z 2005 roku powierzchnia ta powinna wynosić minimum 50\% obszaru upraw, co stanowi obecnie około $7 \mathrm{mln}$ ha [Szydło 2016]. Ustawowa norma jest określana na podstawie miernika powierzchni ubezpieczonych upraw i oblicza się ją jako iloraz powierzchni ubezpieczonych upraw i powierzchni gruntów.

\section{Tabela 4}

Ubezpieczony obszar upraw w latach 2012-2016

\begin{tabular}{|c|c|c|}
\hline Rok & Ubezpieczony obszar [ha] & $\begin{array}{c}\text { Miernik powszechności } \\
\text { ubezpieczonych upraw [\%] }\end{array}$ \\
\hline 2012 & 2751438 & 20 \\
\hline 2013 & 3398811 & 24 \\
\hline 2014 & 3269871 & 23 \\
\hline 2015 & 2823606 & 20 \\
\hline 2016 & 2339578 & 17 \\
\hline
\end{tabular}

Źródło: Opracowanie własne na podstawie danych z uzasadnienia do rządowego projektu ustawy o zmianie ustawy o ubezpieczeniach upraw rolnych i zwierząt gospodarskich oraz ustawy o opłacie skarbowej [anonim (b.d.)b] oraz danych MRiRW.

W analizowanym okresie według danych MRiRW wartość omawianego współczynnika oscylowała w przedziale 17-24\%. (tab. 4). Największy obszar upraw został objęty ochroną ubezpieczeniową w 2013 roku - 3,4 mln ha, a najmniej upraw rolnych było ubezpieczonych w 2016 roku $-2,3 \mathrm{mln}$ ha.

Ministerstwo Rolnictwa i Rozwoju Wsi zakłada, że na skutek wprowadzonych zmian w systemie ubezpieczeń upraw powierzchnia objęta ochroną zwiększy się i osiagnie poziom odpowiednio: w 2018 roku - 36,20\% (5 mln ha), w 2019 roku - 43,40\% (6 mln ha) oraz w 2020 roku - 50,66\% (7 mln ha)-poziom minimalny z ustawy [Szydło 2016].

Biorąc pod uwagę doświadczenia z okresu 2012-2016, tj. wysokości miernika powszechności upraw, powyżej przedstawione prognozy należy uznać za zbyt optymistyczne. 


\section{Dotacje z budżetu państwa do ubezpieczeń upraw rolnych w latach 2012-2016}

W okresie 2012-2015 przeciętna roczna wartość dotacji państwowych do ubezpieczeń rolnych nie przekraczała $174 \mathrm{mln}$ zł (tab. 5). W 2016 roku, w związku wprowadzeniem zmiany wysokości dopłaty do składki z 50 do $65 \%$ i widocznym wzrostem zainteresowania produktami ubezpieczeniowymi wśród rolników, wartość dotacji rządowej osiagnęła poziom ponad $208 \mathrm{mln}$ (przekraczając planowany budżet o $7 \mathrm{mln}$, informacje MRiRW) (tab. 5). W kolejnych latach 2017-2026, z uwagi na przewidywany wzrost powierzchni upraw objętych ubezpieczeniem, dotacja państwowa na ubezpieczenia rolne ma wzrosnąć jeszcze bardziej i wynieść w 2017 roku - $725 \mathrm{mln}$ zł, w 2018 roku - $957 \mathrm{mln}$ zł, w 2019 roku - 1,2 mld zł, a od 2020 do 2026 roku - nawet 1,4 mld zł [Dz.U. 2017, poz. 2047].

\section{Tabela 5}

Kwota dotacji z budżetu państwa do ubezpieczeń w rolnictwie, składka pobrana przez ubezpieczycieli oraz wypłacone odszkodowania

\begin{tabular}{|c|c|c|c|c|}
\hline Rok & $\begin{array}{c}\text { Kwota dotacji } \\
\text { [mln zł] }\end{array}$ & $\begin{array}{c}\text { Składka pobrana } \\
\text { [mln zł] }\end{array}$ & $\begin{array}{c}\text { Kwota wypłaco- } \\
\text { nych odszkodo- } \\
\text { wań } \\
\text { [mln zł] }\end{array}$ & $\begin{array}{c}\text { Stosunek składki } \\
\text { do odszkodowań } \\
{[\%]}\end{array}$ \\
\hline 2012 & 162 & 285 & 719 & 40 \\
\hline 2013 & 164 & 378 & 151 & 250 \\
\hline 2014 & 161 & 355 & 264 & 135 \\
\hline 2015 & 173 & 375 & 172 & 218 \\
\hline 2016 & 208 & 320 & 659 & 49 \\
\hline \hline Średnia & 174 & 343 & 393 & 87 \\
\hline
\end{tabular}

Źródło: Opracowanie własne na podstawie danych z uzasadnienia do rządowego projektu ustawy o zmianie ustawy o ubezpieczeniach upraw rolnych i zwierząt gospodarskich oraz ustawy o opłacie skarbowej [anonim (b.d.)a] oraz danych MRiRW.

Znaczące różnice w wysokości wypłaconych świadczeń wynikały z realizacji jednego tylko ryzyka - ujemnych skutków przezimowania, które w 2012 roku stanowiły $588 \mathrm{mln}$ zł (ok. 82\% wszystkich wypłaconych odszkodowań). W 2016 roku ujemne skutki przezimowania pochłonęły $434 \mathrm{mln}$ zł (czyli ok. 66\% wypłaconych odszkodowań). Średnio w latach 2012-2016 stosunek składki pobranej do wypłaconych odszkodowań wynosił $87 \%$, co oznacza, że na każdy $1 \mathrm{mln}$ zł pobranej składki zakłady ubezpieczeniowe wypłaciły w formie odszkodowań $1,15 \mathrm{mln}$ zł. Wskazuje to na brak rentowności tych usług dla zakładów 
ubezpieczeniowych. Rentowność dotowanych ubezpieczeń rolnych z punktu widzenia zakładów ubezpieczeniowych określa się na podstawie stosunku wielkości składki przypisanej (składka pobrana od rolnika + dotacje budżetu państwa) do wypłaconych odszkodowań. W latach 2012-2016 wypłacone przez zakłady ubezpieczeniowe odszkodowania wyniosły ponad 2 mld zł, a składka przypisana wyniosła około 1,7 mld zł. Deficytowość tych produktów dla zakładów ubezpieczeniowych w dłuższej perspektywie może oznaczać rezygnację ze świadczenia tych usług.

Brak rentowności opisywanych produktów może zatem istotnie wpłynąć na liczbę podmiotów świadczących ochronę ubezpieczeniową upraw. W 2016 roku produkty takie oferowały zaledwie 3 spośród wszystkich 34 krajowych zakładów ubezpieczeniowych (w dziale II), przy czym aż 50\% omawianego rynku obsługiwał tylko 1 podmiot - PZU (szacunki własne).

\section{Propozycje usprawnień systemu ubezpieczeń upraw}

Szansą na poprawę funkcjonowania omawianych produktów ubezpieczeniowych w Polsce jest zwiększenie powszechności ich stosowania przez producentów rolnych. Poniżej zaprezentowano dwie propozycje usprawnień systemu ubezpieczeń w tym zakresie.

Wariant pierwszy zakłada wprowadzenie wymogu sprawozdawczego w odniesieniu do ubezpieczonych upraw, łącznie z wnioskiem o płatność bezpośrednią.

Zgodnie z obowiązującymi przepisami krajowymi producenci rolni korzystający z dopłat bezpośrednich są zobowiązani do ubezpieczania co najmniej $50 \%$ swoich upraw. Proponowana zmiana zakłada dodanie do obowiązującego formularza pola, w którym wnioskodawca określałby udział procentowy powierzchni jego upraw, które zostały ubezpieczone, ze wskazaniem rodzaju ryzyka oraz sumy ubezpieczenia. Wymóg ten dotyczyłby roku poprzedzającego rok sprawozdawczy.

Uzyskanie informacji o sumie ubezpieczenia pozwoliłoby ustawodawcy urealnić maksymalne sumy ubezpieczenia dla poszczególnych upraw. Z kolei sam wymóg sprawozdawczy poskutkuje zwiększeniem zainteresowania rolników produktami ubezpieczeniowymi, przez co może się przyczynić do wzrostu powszechności tych produktów.

Wariant drugi zakłada opracowanie procedur likwidacyjnych dotyczących szkód w uprawach. Podstawą wariantu jest określenie wytycznych dotyczących sposobu szacowania rozmiaru szkód w uprawach (mających w szczególności charakter katastroficzny, tj. powódź, susza, ujemne skutki przezimowania, 
przymrozki wiosenne) oraz wysokości należnego odszkodowania. Wytyczne zostałyby opracowane przez specjalnie powołany zespół, składający się z przedstawicieli zarówno zakładów ubezpieczeniowych, Ministerstwa Rolnictwa i Rozwoju Wsi, jak i producentów rolnych. Uzgodnione regulacje zostałyby poddane dalszemu procesowi legislacyjnemu i opracowane w formie aktu prawnego, na przykład rozporządzenia lub ustawy.

Zaproponowane rozwiązanie może przyczynić się do zwiększenia powszechności ubezpieczeń upraw, ponieważ ujednolicone w ten sposób procedury przyznawania odszkodowań staną się bardziej czytelne i jednoznaczne dla rolników.

\section{Podsumowanie}

Wzrost powszechności korzystania z ubezpieczeń upraw w Polsce jest konieczny, a kolejne modyfikacje tego systemu są niezbędne.

Modyfikacje krajowego systemu dotowanych ubezpieczeń upraw, dla którego aktualnie weryfikowane są zasady przejściowe, mają zapewnić rolnikom większą dostępność tych produktów. Kluczowym problemem w tym obszarze są koszty i dostępność ochrony ubezpieczeniowej, które niejednokrotnie uniemożliwiały producentom rolnym nabycie polisy ubezpieczeniowej.

System ubezpieczeń upraw w Polsce powinien zapewniać producentom rolnym adekwatną oraz przystępną cenowo ochronę ubezpieczeniową. Tym czasem wytyczne wynikające z obowiązującej ustawy z 2005 roku koncentrują się głównie na zmniejszeniu kosztów tej ochrony poprzez zwiększenie dofinasowania składki z poziomu 50 do $65 \%$ i rozszerzenie zakresu ubezpieczenia przez wprowadzenie pakietów ryzyka. Jednocześnie powoduje ograniczenie zainteresowania ubezpieczycieli świadczeniem ich usług, obniżając maksymalny poziom subwencjonowanej składki do 9\%. W konsekwencji zakłady ubezpieczeniowe mogą ograniczyć swoją ofertę lub wycofać się z tego rynku.

Zaproponowane rozwiązanie dotyczące wymogu sprawozdawczego w zakresie ubezpieczeń upraw może przyczynić się do wzrostu świadomości ubezpieczeniowej rolników, a w konsekwencji do zwiększenia powszechności tych produktów ubezpieczeniowych.

Prezentowana zmiana polskiego systemu ubezpieczeń upraw polegająca na opracowaniu procedur likwidacyjnych $\mathrm{w}$ zakresie przyznawania i szacowania odszkodowań może wpłynąć na poprawę jego czytelności i jednoznaczności dla producentów rolnych. 


\section{Literatura}

Anonim [b.d.]a: Projekt ustawy o zmianie ustawy o ubezpieczeniach upraw rolnych i zwierząt gospodarskich oraz ustawy o opłacie skarbowej, http://www.mir.krakow.pl/resources/articles/9323/13_2016\%20proj\%20ustawy\%20o\%20ubezpieczeniach\%20rol\%20i \%20oplacie\%20skarbowej.pdf [dostęp: 04.12.2017].

Anonim [b.d.]b: Uzasadnienie do projektu o zmianie ustawy o ubezpieczeniach upraw rolnych i zwierząt gospodarskich, https://legislacja.rcl.gov.pl/docs//2/12281402/12334151 /12334152/dokument209144.pdf [dostęp: 04.12.2017].

HEERMAN K.E.R., COOPER J., JOHANSSON R., WORTH T., 2016: Farmer Response to Crop Insurance Incentives under Heterogeneous Risk-Management Strategies. Annual Meeting, 31.07.-02.08.2016, Boston, Massachusetts, http://purl.umn.edu/235967 [dostęp: 04.12.2017].

JANOWICZ-LOMOTT M., ŁYSKAWA K., 2016: Funkcjonowanie dotowanych ubezpieczeń upraw w Polsce, Wiadomości Ubezpieczeniowe 2, 69-92.

LORANT A., FEKETE F.M., 2015: More Insurance Subsidies for European Farmers - Is It Needed?, Applied Studies in Agribusiness and Commerce - Apstract 9 (4), 33-38.

ŁYSKAWA K., 2015: Historyczny rozwój rynku ubezpieczeń upraw w Polsce, [w:] M. Kaczała, K. Rojewski (red.), Ubezpieczenia produkcji roślinnej w Polsce, Poltext, Warszawa, 77-102.

MALIK A., 2016: Ocena ryzyk ubezpieczeniowych w obowiazkowym ubezpieczeniu upraw rolnych, Studia Iuridica Agraria 14, 373-388.

Obwieszczenie Marszałka Sejmu Rzeczypospolitej Polskiej z dnia 16 października 2017 r. w sprawie ogłoszenia jednolitego tekstu ustawy o ubezpieczeniach upraw rolnych i zwierząt gospodarskich, Dz.U. 2017 r., poz. 2047.

PIET L., BOUGHERARA D., 2016: The Impact of Farmers' Risk Preferences on the Design of an Individual Yield Crop Insurance, Working Papers SMART - LERECO, INRA, UMR SMART 16-03.

ROJEWSKI K., 2012: Historia i stan obecny ubezpieczeń rolnych $w$ Polsce, [w:] Trendy $w$ ubezpieczeniach rolnych $w$ Europie. Ubezpieczenie ryzyka suszy $w$ Polsce, materiały konferencyjne, 05.11.2012, Polska Izba Ubezpieczeń w Warszawie, Warszawa, https://piu.org.pl/public/upload/ibrowser/Mnrd\%20Konf\%20Rolna/1\%20Historia$\% 20 \mathrm{i} \% 20$ stan\% 20obecny\%20ubezpiecze $\%$ C5\%84\%20rolnych\%20w\%20Polsce $\% 20$ \%20K.pdf [dostęp: 04.12.2017].

Rozporządzenie Komisji (WE) nr 702/2014 z dnia 25 czerwca 2014 r. uznające niektóre kategorie pomocy w sektorach rolnym i leśnym oraz na obszarach wiejskich za zgodne z rynkiem wewnętrznym w zastosowaniu art. 107 i 108 Traktatu o funkcjonowaniu Unii Europejskiej, Dz.Urz. UE L 193/1 z 01.07.2014.

Rozporządzenie Komisji (WE) nr 1857/2006 z dnia 15 grudnia 2006 r. w sprawie stosowania art. 87 i 88 Traktatu w odniesieniu do pomocy państwa dla małych i średnich przedsiębiorstw prowadzących działalność związaną z wytwarzaniem produktów rolnych oraz zmieniające rozporządzenie (WE) nr 70/2001, Dz.Urz. UE L 358/3 z 16.12.2006. 
Rozporządzenie Prezydenta Rzeczypospolitej z dnia 27 maja 1927 r. o przymusie ubezpieczenia od ognia i o Powszechnym Zakładzie Ubezpieczeń Wzajemnych, Dz.U. R.P. $1926 \mathrm{nr}$ 46, poz. 410.

Rozporządzenie Rady Ministrów z dnia 1 lutego 1972 w sprawie obowiązkowego ubezpieczenia ziemiopłodów od gradobicia i powodzi, Dz.U. $1972 \mathrm{nr}$ 5, poz. 25.

Szydło B., 2016: Uzasadnienie do projektu o zmianie ustawy o ubezpieczeniach upraw rolnych i zwierząt gospodarskich, http://orka.sejm.gov.pl/Druki8ka.nsf/0/ EC0E36A8DA031D21C1257FA4002FF729/\%24File/469.pdf [dostęp: 04.12.2017].

Ustawa z dnia 28 marca 1952 r. o ubezpieczeniach państwowych, Dz.U. $1952 \mathrm{nr}$ 20, poz. 130.

Ustawa z dnia 20 września 1984 r. o ubezpieczeniach majątkowych i osobowych, Dz.U. 1984 nr 45, poz. 242.

Ustawa z dnia 28 lipca 1990 r. o działalności ubezpieczeniowej, Dz.U. 1990 nr 59, poz. 344, z późn. zm.

Ustawa z dnia 7 lipca 2005 r. o ubezpieczeniach upraw rolnych i zwierząt gospodarskich, Dz.U. 2005 nr 150, poz. 1249, z późn. zm.

\section{Abstrakt}

W artykule podjęto próbę analizy funkcjonowania dotowanych ubezpieczeń upraw w Polsce w latach 2012-2016. Oceniono zmiany, którym poddano system ubezpieczeń upraw. Wskazano na deficytowość tych produktów dla zakładów ubezpieczeniowych oraz brak powszechności nabywania polis przez producentów rolnych w Polsce. Artykuł zawiera propozycje zmian, które mogą wpłynąć na poprawę funkcjonowania tych ubezpieczeń, zarówno po stronie popytu, jak i podaży.

Słowa kluczowe: ryzyko ubezpieczeniowe, ubezpieczenie upraw, ubezpieczenia rolne 


\title{
Subsidized crop insurance in Poland. Status and prospects
}

\begin{abstract}
The article is an attempt to analyze the functioning of subsidized crop insurance in Poland in 2012-2016. The evaluation of crop insurance has been done. Negative effectiveness of these products for insurance companies and the lack of universality in the acquisition of policies by agricultural producers in Poland were observed. The article proposes changes that may improve the functioning of these insurances, from demand and supply point of view.
\end{abstract}

Key words: insurance risk, crop insurance, agricultural insurance 
